Article

\title{
Working Stiff(s) on Reality Television during the Great Recession
}

\section{Sean Brayton}

Department of Kinesiology and Physical Education, University of Lethbridge, 4401 University Drive, Lethbridge, AB, T1K 3M4, Canada; E-Mail: Sean.brayton@uleth.ca

Received: 6 August 2012; in revised form: 22 October 2012 / Accepted: 23 October 2012 /

Published: 29 October 2012

\begin{abstract}
This essay traces some of the narratives and cultural politics of work on reality television after the economic crash of 2008. Specifically, it discusses the emergence of paid labor shows like Ax Men, Black Gold and Coal and a resurgent interest in working bodies at a time when the working class in the US seems all but consigned to the dustbin of history. As an implicit response to the crisis of masculinity during the Great Recession these programs present an imagined revival of manliness through the valorization of muscle work, which can be read in dialectical ways that pivot around the white male body in peril. In Ax Men, Black Gold and Coal, we find not only the return of labor but, moreover, the re-embodiment of value as loggers, roughnecks and miners risk both life and limb to reach company quotas. Paid labor shows, in other words, present a complicated popular pedagogy of late capitalism and the body, one that relies on anachronistic narratives of white masculinity in the workplace to provide an acute critique of expendability of the body and the hardships of physical labor.
\end{abstract}

Keywords: reality television; masculinity; working-class bodies; labor; late capitalism

\section{Introduction}

There is a scene in John Wells' recent film The Company Men (2010) where a jobless Bobby Walker lays beside his wife Maggie. As victims of the Great Recession, the couple bickers over solutions to mounting debt and mull over the prospects of temporary employment. Once a corporate executive, Bobby now struggles to accept a life of less privilege and is unwilling to forego his creature comforts. Facing imminent foreclosure on their sprawling home, Maggie suggests to Bobby the possibility of working with her brother Jack, a tradesman who specializes in drywall installation. When 
Bobby scoffs at the idea, Maggie adds it would "get [him] back into great shape: calluses, a tan, and big broad shoulders from carrying all that heavy lumber." Aroused by the thought of muscle work and hoping her husband might warm to the idea, Maggie attempts to seduce Bobby, who turns a cold shoulder to end the conversation. This particular scene captures the subtext of a film in which physical labor and working-class bodies are an absent presence, marginalized as characters but romanticized as a site of moral and masculine renewal. Bobby eventually finds work with Jack, who teaches the green horn the value of both physical labor and family. Here blue-collar life provides the white-collar protagonist with masculine repair, humility and temporary employment before his return to an apparently kinder, gentler corporate gig. In other words, working-class bodies produce a cinematic surplus value of sorts through which middle-class men find recovery and redemption.

Of course The Company Men is not unique in its focus on the peril of the managerial class after 2008. It participates in a wider discursive field that includes not only narratives of the Great Recession and the crisis of middle-class masculinity but also a resurgent interest in working-class bodies, especially on reality television. To understand the symbolic significance of working-class bodies, both on reality television and in the wider culture, it is imperative to account for the ways in which narratives of the Great Recession are heavily gendered. Clearly, the economic meltdown has accelerated the "hollowing-out of the middle class," a condition often presented as "inseparable from the economic troubles of men" [1]. Of the 8.5 million jobs lost since 2008 , for instance, $80 \%$ belonged to men [2]. In that same year only $69 \%$ of American men had steady employment, the lowest percentage in US history [2]. Such a sea-change led many cultural commentators to declare yet another crisis of masculinity, this time of epic proportions among (but not exclusive to) middle-class men. Since 2008, media pundits and journalists have repeatedly asked if manhood could survive the recession, pointing to the increasing number of college-educated white men left without fulltime employment [3]. In The Atlantic, Hanna Rosin sardonically forecasted the "end of men," especially in the workplace where women now "hold a majority of the nation's jobs" [4]. The current situation for middle-class men is supposedly dire, prompting Rick Marin of The Daily Beast to declare them "dead suits walking" [3]. Marin added that "the same guys who once drove BMWs ... have now been downsized to BWMs: Beached White Males." Again the crisis of masculinity is synonymous with the crisis of the middle class, which is "often used as a stand-in for the future of America" [3].

The turmoil of the Great Recession and its effects on the gender order are readily apparent in popular film and television. In addition to The Company Men, we find documentaries like The End of Men (2011) and Hollywood films like Up in the Air (2009), Wall Street: Money Never Sleeps (2010), Too Big to Fail (2011), Tower Heist (2011) and Margin Call (2011), all of which situate the economic collapse alongside the strengths and weaknesses of maverick but increasingly vulnerable middle-class masculinities. On network television, sitcoms like Man Up! (2011), Last Man Standing (2011) and Up All Night (2011) illustrate the emotional and economic instability of middle-class men and their (in)ability to provide for their families during the Great Recession. In many of these texts viewers learn of the perceived catastrophe and middle-class nightmare of seeking out casual unskilled employment and coming to terms with expendability and the evaporation of a family income once thought intrinsic to affluent American households. Such narratives focus on the struggles of unemployed office workers and businessmen, despite the devastating effects of the Great Recession on manufacturing and the construction industry as well as the US Senate's \$17.4 billion bailout of 
American automakers. Even Oliver Stone's recession-era Wall Street: Money Never Sleeps displaces the same working class that provided the moral center of the original Wall Street (1987) film. While widespread attention to corporate plundering and unemployed middle-class men is important it offers a myopic understanding of labor and economic collapse. Whither the working class?

Although Hollywood has shown considerable attention to the economic meltdown of 2008, its interest in the emasculating traits of corporate culture is not new. Since the early-1990s we find a set of office movies in which white male protagonists were trapped in the middle rungs of large corporations, disenfranchised and desperate to escape the humdrum of middle-class employment. Films like Glengarry Glen Ross (1992), Falling Down (1993), In the Company of Men (1997), American Beauty (1999) and Fight Club (1999), for instance, detailed the disillusion and displacement of middle-class white men in corporate America. While some office films presented an angry white male, others provided a more sardonic approach to the office cultures of late capitalism, middle-class monotony and marketplace masculinities. Films like Office Space (1999) and Waydowntown (2000) as well as television programs like The Office (2005-present), Just Shoot Me (1997-2003), Better Off Ted (2009-2010) and Parks and Recreation (2009-present) used social satire to trace the corporate confusion and complacency to economic shifts, downsizing and redundancies where women, racialized groups and white men were equally effected by layoffs and corporate restructuring. The Office and Office Space, in particular, provided nuanced reflections on the proletarian aspects of white-collar work in a post-industrial America. Here, white-collar employees were often positioned against the working stiffs of the warehouse and construction industries, which provided both tension and an imagined site of masculine revival for the middle-class protagonists. Clearly there is some historical continuity between the office films of the 1990s and Hollywood commentaries on the Great Recession, which magnify how a crisis of middle-class masculinity is articulated at the expense of working-class characters and themes.

If the recent strain on masculinity and (un)employment is expressed from a middle-class perspective in Hollywood, it unfolds in markedly different ways on reality television, where we now find a cycle of paid labor shows like Ax Men (2008), Black Gold (2008) and Coal (2010). While such programs complement a welter of reality shows interested in manual labor-from Dirty Jobs (2003present), Undercover Boss (2009-present) and Gold Rush (2010) to Duck Dynasty (2012), Highway Thru Hell (2012) and Moonshiners (2012)—Ax Men, Black Gold and Coal provide perhaps the most explicit visual narratives of muscle work. Here viewers learn of the danger and hardships of white men working in logging, drilling and mining, traditional industries far removed from the machinations of Wall Street. At a time when the working class in the US seems all but consigned to the dustbin of history, these paid labor shows are keenly interested in soot-collared work, which complicates dominant discourses of the Great Recession and can be read as an implicit response to the current crisis of American manhood. These programs, in other words, present an imagined revival of masculinity through the valorization of muscle work, which can be read in dialectical ways that pivot around the white male body in peril. Using Ax Men, Black Gold and Coal as illustrations, I argue that while certain retro masculinities are highly problematic they arise in and through narratives of physical labor, danger and a latent form of class conflict that both enables and constrains a more comprehensive understanding of economic struggle. Although each storyline is predicated on the visibility of workingclass bodies, the purpose of this essay is not to excavate and refurbish the proletariat as the "necessary lever" of social change [5]; instead it is to identify and discuss some of the ways in which labor-as 
the source of value in late capitalism-is re-embodied on reality television after the economic crisis of 2008.

\section{Class, Bodies and Reality Television}

This analysis of working-class bodies is informed by what Douglas Kellner calls a "contextual cultural studies" approach, which seeks to examine how the meanings of particular media texts reflect and react against wider social, political and economic conditions as well as conflicts [6]. For Kellner, this involves "doing ideological analysis within the context of social theory and social history" and identifying moments in which the text produces paradoxical messages that encourage complicity and occasionally contestation of a dominant social order ([6], p. 103). Taken together, various texts present an intersection of language and power relations that condition our understanding and set the limits of intelligibility of a particular topic, such as the body. Indeed, it is in and through representations and discursive practices that the body becomes a cultural sign, a repository of various ideologies of race, gender, class, empire, age and ability. In her classic discussion of self and society, Mary Douglas described a reciprocating relationship between the physical body and the social body whereby the former is a metonym of the latter [7]. Much as the "social body constrains how the physical body is perceived and experienced," the values and tensions of a particular society are embodied and can be "decoded" as such (though never with absolute certainty) [8].

What we might call the semiotics of the body, then, are often inflected by socioeconomic class such that status and physical capital, for instance, are embodied and performed through an idiom of sorts $[9,10]$. As George Orwell once remarked, in the bourgeois imaginary the "real secret of class distinctions" is that "the lower classes smell" [11]. If the working-class body is a social symbol, however, it is saturated with competing ideas of civic pride, economic change and shifts in the gender order. The steelworker's body, for example, inspired artistic renderings in cities across the US and was proudly displayed at civic exhibitions and public venues as a symbol of growth and prosperity, especially in Pittsburgh during the late 1800s [12]. In many renderings, however, the worker's body was removed from the workplace where it was forged, presenting a sanitized version of class relations and a steel town "on the rise" ([12], p. 9). That "work shaped, stressed and ultimately possessed bodies" has been a truism of socialist critiques of the labor process ([12], p. 148). Harry Braverman illustrated in great detail how early industrial management theorists like Frederick Taylor and Elton Mayo imagined the worker's body as a subject of not only discipline and surveillance but, more precisely, scientific measurement and optimization [13]. Nikolas Rose adds that factory owners' keen interest in the health and wellbeing of industrial workers was driven less by bourgeois goodwill than an unrelenting desire to increase production and capital [14].

But working bodies are hardly homogenous; instead, they are disparately divided by race, ethnicity, gender, sexuality and citizenship. In her discussion of technology and embodiment, Anne Balsamo explains how the outsourcing and exploitation of manual labor in the microelectronics industry is rationalized through racist and sexist assumptions of south-east Asian women as innately nimble and indefatigable [15]. In North America, Gilbert Gonzalez identifies an "imperialist schema of colonial labor" in which certain types of demeaning work are racialized through past and present migrant worker policies that leverage temporary visas and precarious citizenship to disempower and indenture 
Mexican fieldworkers, Caribbean housekeepers and Filipino domestics, for instance [16]. Conversations around the working body have also included the sex industry, where themes of commodification and what bell hooks famously calls the "white supremacist capitalist patriarchy" operate in multiple ways. Becki Ross, for instance, situates striptease as a form of capitalist production, charting the various obstacles to labor organization among sex workers in western Canada during the 1950s [17]. Here the term body work might explain how the appearance of the body is increasingly commodified, a condition well-nigh intrinsic to the service and hospitality industries. Airline companies, for example, have historically demanded female flight attendants to undergo ostentatious grooming and dieting in addition to enduring chronic back pain and sciatica caused by the requisite stiletto footwear of in-flight labor $[18,19]$.

The toll of toil on the body is perhaps most vividly described in the writings of workers themselves, like Paul Romano and Ria Stone, Harvey Swados, Ben (Rivethead) Hamper and Barbara Ehrenreich [20-23]. In 'shop rat' memoirs the working-class body often emerged in grotesque ways, as a brutalized byproduct of industrial production. Whereas Romano and Stone detailed the garish bodies of American factory workers with "oil pimples, rashes and sores" ([20], p. 2), Hamper described the assembly line as a "slaughterhut full of foul-smellin' mutants ... [who] looked like trash" and resembled the "brainless ghouls in a George Romero flick" ([22], pp. 45, 59, 126). For Hamper, however, such bodies were also icons of stalwart masculinity:

"The closest thing I ever saw to an authentic American champ for the masses was a sweaty piece of ground chuck in a Black Sabbath t-shirt who strode upon Hades' own loading dock, night after hopeless night, as invincible in his death web as he was invisible to the rest of the feeble globe." ([22], p. 134)

Here the working-class body was emblematic of empathy, admiration and, when "the machine inflicts its greatest damage," looming revolt ([20], p. 32). Evidently, factory life and the "death march of the minute hand" produced not only disfigured bodies but also some colorful narratives through which we learn of them ([22], p. 134).

The meanings of a working-class body, however, are neither permanent nor singular; instead, they are shaped by specific social and historical conditions, creating what Stuart Hall calls a "non-necessary correspondence" between the ideologies of a text and the subjects it aims to interpellate [24]. In short, bodies are "invested with a wide range of shifting and unstable meanings" that resonate with interpretive communities in sometimes unpredictable ways ([8], p. 65). Today, an image of the craggy factory worker (the rivethead) may seem like a vestige of labor struggles from times passed, a nostalgic rendering of white masculinity incongruous with the automated conditions and demographic shifts within working-class America. And yet the same images of working bodies that may have receded during times of economic prosperity in service industries now maturate in the wake of economic collapse, massive waves of unemployment and masculine anxiety during the Great Recession, especially on reality television.

A quick glance at cable and network programming would suggest that reality television now includes a constellation of subgenres, many of which overlap. Typically, it differs from fictional programming in its appeal to authenticity, normalization of surveillance, use of "advertainment" (where produce placement drives the narrative) and "image-entrepreneurship" as well as low production costs [25-28]. Within this broad genre the body is often a central site of production, 
consumption and transformation. The makeover show, for example, inculcates its participants and viewers with a fantasy of upward social mobility and middle-class morals used to judge and discipline working-class bodies. In The Swan (2004), The Biggest Loser (2004-present), What not to Wear (2003-present) and Extreme Makeover (2002-2007) participants move from rags to riches by undergoing physical and sartorial transformations that "universalize middle-class lifestyles" by promoting urban affluence and "self-management" [29]. Such programs also illustrate what Chris Shilling calls the "social reproduction of appropriate bodies" whereby the working-class bodybroadly presented as obese, dirty and undesirable - is the subject of observation and intervention ([8], p. 109). A similar spectacle of class and middle-class voyeurism underwrites a range of docusoaps, which feature images of the super-rich in the Real Housewives franchise (2006-present), Keeping up with the Kardashians (2007-present) and The Hills (2006-2010) to exposés of the working class in Dog the Bounty Hunter (2004-present), Swamp People (2011) and Jersey Shore (2009-present). From clothing and curves to mullets and muscles, meanings of class pivot around the body as a cultural sign. While many reality programs reveal the work of body projects-epitomized by the gym, tan and laundry (GTL) mantra of Jersey Shore - few have focused solely on the body at work.

Recent programs like Deadliest Catch (2005-present) and Ice Road Truckers (2007-present), however, mark a new genre of paid labor shows and a watershed of working bodies on reality television. Herein lies "a growing alternate universe of hit reality series about workers no one puts in sitcoms anymore ... [where] TV hosts embrace their inner Woody Guthrie and rediscover the workin' man" [30]. Created, produced and narrated by Thom Beers (the impresario of Ax Men, Black Gold and Coal), these early paid labor shows situate physical work in a predictable idiom of masculinity, saving unpaid affective labor and domestic details to the women of programs like Nanny 911 (2004-2007), Supernanny (2004-2011)and Trading Spouses (2004-2007). But they also complicate the middle-class sensibility of reality television by emphasizing the hazards of blue-collar work where fantasies of upward social mobility are notably absent; instead, crab fishermen and long-haul truckers struggle to reach company quotas and make ends meet rather than bask in luxury. The presence of blue-collar work on reality television is not insignificant, especially in an era defined by pervasive unemployment and the 'endangerment' of middle-class men. This is most relevant to the latest cycle of Beers' productions that includes Ax Men, Black Gold and Coal, all of which privilege a rugged but precarious working-class body. At a time when popular culture is preoccupied with the real and perceived plight of the middle class and the loss of white-collar jobs, how can we account for the increasing interest in working-class bodies? Which bodies 'matter' and how are they a conduit of class struggle on network and cable television?

\section{Anatomies of Power in Ax Men, Black Gold and Coal}

It is interesting to note that Ax Men, Black Gold and Coal share the same creator, producers, plot and narrator, inviting the viewer to interpret and enjoy paid labor shows as a collection or franchise. Each program emphasizes intergenerational relations between working fathers (biological and surrogate) and working sons, privileging a pastoral version of masculinity with an intimate understanding of nature and the outdoors. Ironically, each series presents workers' reverence for nature (the forest, American outback and mountains) while vividly documenting the exploitation of that 
nature for profit. Such themes, however, are complicated by the economic fallout of 2008, which provides the narrative backdrop of each series. In an Ax Men episode called Market Meltdown, for example, we learn of looming layoffs in the logging industry of the Pacific Northwest where the housing crunch brought the price of lumber to a twenty-year low. Likewise, the threat of unemployment is central to every episode of Coal, where jobs in West Virginia mines seem precarious at best, and Black Gold, where the livelihood of West Texas roughnecks hangs on the impulses of wealthy oil barons. As one roughneck quips, the owners "are gambling with our jobs." His coworker adds that the oilfield is "like anything else in life: the rich get richer and the poor get fucked!" While the looming threat of unemployment echoes the uncertainties of the modern middle class, paid labor shows are distinctly working class. A driller in Black Gold explains, "We don't work at banks. We don't work at the fucking mall. We work in living hell." As Swados pointed out long ago, the working class may earn, vote, dress and dream like the middle class, but it still "works like a worker. The steel-mill puddler does not yet sort memos, the coal miner does not yet sit in conferences, the cotton millhand does not yet sip martinis from his lunchbox" ([21], p. 237). In Black Gold, shiftless roughnecks are told to "go work at Wal-Mart."

The programs share a formulaic plot driven by competition and accumulation. The respective logging and drilling crews of Ax Men and Black Gold, for instance, race to gather the most loads of lumber and drill total depth before their competitors. Here the rhetoric of competition includes various sports metaphors that provide drama and a ludic euphemism for capitalist accumulation. The CEO of Cobalt Mining, for example, describes every cut of coal as a touchdown in gridiron football. Likewise, the roughnecks in Black Gold compare their toil to the training routine of prizefighting and "making big plays" in high-school football. While the language of sport and gamesmanship in the workplace may encourage us to think of mining and drilling in lighthearted terms, it also consolidates the ways in which the bodies of workers and athletes alike are used and abused in the interests of capital. (In some ways, the programs provide the audience with a version of risk entertainment not unlike the world of extreme sports.) Incidentally, these paid labor shows overlap with recent labor lockouts in professional football and basketball as well as increasing concern for concussions and the deleterious physical effects of contact sports. The rhetoric of sport, in other words, is far from innocent as it aims to minimize how a hastened pace of production adds greater danger to already dangerous occupations. This, however, is not lost on some workers, who gripe about the breakneck speed of production dictated by owners and enforced by management. A driller in Black Gold summarizes the quandary: "You've got the owners saying we gotta hurry up and make money, but you've also got the safety guys saying we gotta be safe. You're kind of screwed between the two of them."

A hazardous workplace is the indelible trademark of paid labor shows. The daily risk of injury and, in some cases, death bolsters the connections between rugged manliness and labor, which of course would erode under safer work conditions. Gerald, the 'legendary' driller of Black Gold, for example, is "missing digits" and belongs to the exclusive Sixteen Club as one of the few and fortunate roughnecks to have fallen from a derrick tower and survived. He explains to his young protégé, "I don't want to see you end up like me-missing fucking body parts." In Ax Men, the owner of Browning logging wears a prosthetic arm, a reminder of early injuries in the logging industry. In Coal, the miners display a stamp on their hardhats to lament the twenty-nine workers killed in the Upper Big Branch mine disaster in 2010. From tangled logs (chaser erasers), swinging chains and hydrogen sulfide leaks to 
heavy tongs, slipping pipes and falling rocks, danger and injuries are commonplace in each program and are often followed by visits to local hospitals. When the senior tool pusher (rig manager) of Black Gold receives a broken nose, thirty-two facial stitches and partial blindness from a snapping chain, he pleads with his physician for written permission to resume work. The narrator claims that Jerry's "pride, job and health are on the line" as the would-be pensioner is aiming for a front-office promotion. Jerry bluntly states, "It's my job. If I don't get back out there I'll be in the unemployment line." We are reminded, however, that "the heavy toll roughnecking takes on the body and soul has a way of making any man think twice."

While each series presents physical ailments and injuries as endemic to the hardships of manual labor, they also place a premium on the bodies of young, muscular men. In Ax Men, the owner of Siderius logging admits the inexperience of his crew but adds, "They'll work as much as two crews 'cause they're young enough to do it." The commodification of strong and youthful bodies, however, is often apparent to the workers. When the Pihl company of Ax Men runs an extra lean crew to save money, a young logger warns of the imminent risk to the body, recalling how his "knees go bad running around, jumping all over the place ... to impress" the boss. A young hook tender quips, "Making Gabe [the owner] money is gonna put my life in danger. Fuck that!" In Black Gold, Junior sprains his back shortly after receiving an impromptu lecture on the merits of learning mathematics (brain work) and admits that "if my body goes, I can't do this." If the roughnecks fail to reach total depth quickly, we are told the owners will "run through their asses like circus horses," a dehumanizing reference to obsolescence, unemployment and labor as chattel. A derrick man adds that the "bosses don't care about us. They work us like slaves, pay us like slaves and there's no job security." Likewise, in Coal a veteran miner explains how "the more money big companies pay you, the more they act like they own you." Such comments confirm that "while working, bodies belonged to the mine owner; they were one more set of tools to wield below ground" ([12], p. 150). For many workers in paid labor shows the body is rented as property to employers and used to earn a living but is ultimately "discarded and replaced when damaged," much like worn machinery [31]. A tool pusher in Black Gold reminds the roughnecks that he will remain on the rig "long after they're gone," implying that laborers are unskilled, easily expendable and prone to serious injury.

These narratives of manual labor are dramatized by a vivid visual economy of the body. In Coal, for instance, miners are svelte and always covered in soot, while the owners are rotund, clean and spend much of the day brokering deals indoors and out of sight from labor. Here the presence of dirt on the working-class body is richly symbolic within the relations of production. As Anne McClintock notes, "dirt is the visible residue that stubbornly remained after the process of industrial rationality had done its work. Smeared on clothes, hands, and faces, dirt was the memory trace of human labor, the evidence that the production of industrial wealth, and the creation of liberal rationality, lay in the hands and bodies of the working class and the colonized" [32].

In Coal, dirt on the body is unavoidable for the miners. Even at ground level, miners appear with blackened faces and hands as they explain the strain of their jobs and the autocratic practices of owners and supervisors, who are predictably unsoiled, coiffed and in the comfort of the front office. A sootcovered miner describes to the camera the "piss-poor management" skills of the owners who "run eighteen-hour days with no maintenance" and "push everything to the maximum." While the miner is referring to equipment and machinery, the smudged dirt and debris on his face and coveralls provides 
"visual evidence of manual labor," telling us that "overworked machines" are dependent on human operators and are perhaps synonymous with the coalminer's body [33]. A staple of paid labor shows, dirt marks the extraction of value from the working body and positions physical labor as instrumental to logging, drilling and mining industries, despite the deprecation from owners and managers.

While a semiotics of dirt can be found in most paid labor shows, somatotypes are most conspicuous in Black Gold where physical differences correspond closely with divisions of labor. Drillers, floor hands and derrick men, for instance, are depicted as muscular, tattooed, youthful and more or less active. In contrast, tool pushers, supervisors and owners are presented as flabby, groomed, aging and sedentary. Disputes between tool pusher Freddy and the roughnecks are typically framed within a Cartesian idiom. Whereas Freddy routinely insults roughnecks' apparent lack of intelligence, describing the floor hands as "a bunch of monkeys trying to fuck a football," the crew openly refers to the tool pusher as "the fat man," whose love of fried chicken and cherry pie is disclosed to the viewers. Evidently, banter between the tool pusher and the roughnecks is outlandish and directed towards both body and mind. If a visual economy of the body highlights friction between mesomorphic labor and endomorphic management, however, it tends to displace and diffuse wider animosity towards the owners. The audience of Black Gold receives regular updates on the gambles and deals made by oilman Autry Stephens, whose rare visits to the rig render ownership relatively invisible to the roughnecks. As a result, conflict between labor and capital is re-routed towards "the fat man" (who resembles a Foghorn Leghorn to the chicken hawk roughnecks). Freddy, rather than Autry, is described by the roughnecks as a "third-world dictator" and "slave-driver" despite the fact that production mandates are issued well above the rank of the cartoonish tool pusher.

Nevertheless, tension between labor and management, or rather body and mind, is routine in paid labor shows. As Braverman noted, the linchpin to managing labor in industrial capitalism was the rigorous separation of conception (brain) and execution (hands). While this streamlined the production process, it also disempowered labor and created "antagonist social relations [where] hand and brain become ... divided and hostile, and the human unity of hand and brain turns into its opposite, something less than human" ([13], p. 125). Such divisions are prevalent in Black Gold, where roughnecks are typically referred to as hands. The moniker and metonym epitomizes Braverman's observations and draws particular attention to the body as the source of value in the oilfields, much like "farmhands," "dockhands" and "hired hands" in the "epoch of emerging capitalism" [34]. Drillers explain that "if you take care of your 'hands,' they'll take care of you," a reference to both workers and body parts. While the hands of the roughnecks are active, dirty, callused and sometimes bloody, the hands of management are often clean, concealed in pockets, tucked in suspenders and generally inactive. As one roughneck suggests, Freddy's hands are better suited for pointing and gesticulating than lifting and laboring. When the roughnecks reflect on the hardships of the oilfield, the camera provides close-up shots of battered hands and dirty fingernails as if to emphasize the extraction of value from the body. Incidentally, such footage of working bodies complements various television adverts for Chevy, Dodge and Ford trucks as well as tools like Irwin vise grips, whose tagline is: "Here's to the hands that keep our country going strong. They may not be pretty but they sure make us proud." Herein lies an intertextual form of advertainment where the roughnecks of Black Gold drive American-made trucks and the actors in the Chevy, Dodge and Ford adverts all resemble roughnecks in the depiction of dirt, danger and muscle work. So in many ways, the roughnecks and their roles in 
the oilfield are reduced to their bodies (hands, in particular), which become ironic symbols of perseverance in the harsh economic climate of Black Gold.

The valorization of physical labor and the male body, however, works in curious and contradictory ways. Within the mostly male settings, the narrative (dis)placement of females strengthens both homosocial bonds and the alleged monopoly of manual labor by manly men, leaving women and henpecked husbands for other lines of work (and middle-class sitcoms). While women appear in slightly more nuanced roles as physicians and former miners and are instrumental to the reproduction of labor in Coal, they are framed as a looming threat to the jobs and fraternity of roughnecks in Black Gold; Brandon's girlfriend is unhappy with his ungodly hours of work, claiming to have once dreamt of marrying a doctor or a lawyer; Gerald's wife repeatedly worries for her husband's safety and pleads with him to leave the oilfields; Tank is abandoned by his wife in Season Three for being "married to the oilrig." The only female character to appear with regularity in Black Gold is Peggy, the stingy land owner who threatens to revoke the drilling lease in Seasons Three and Four. Collectively, the women in Black Gold are positioned as an obstacle to employment and by extension rugged masculinity which is, however, ambiguously heteronormative. While the camera is rather fond of filming workers toil in the "third deadliest job in the world" it also catches taut young men disrobing, bathing and spraying each other with water hoses, antics described by Peggy as a game of "grab-ass." By day, the camera follows a group of strapping men wrestling with gushing pipes, lassoing long steel shafts and erecting derrick towers. By night, it persuades the audience (and perhaps the workers as well) of the cast's heteronormativity by visiting Hooters restaurant, coed pool parties and local bars stocked with young women. In other words, the working-class bodies designed to signify hegemonic masculinity in Black Gold are open to ironic if not disruptive interpretations; the shirtless working man is more than merely a sign of physical labor.

If the working-class body is presented as an object of desire, it is also an object of intense surveillance and scrutiny by management. In the West Texas oilfields, anytime a roughneck is injured on a rig the entire crew must undergo drug testing. When Terry (Tank) Hannon fails a drug test and is immediately fired, he oddly disrobes to reveal his inflated and tattooed upper body while muttering his disappointment. While Tank accepts responsibility for his actions, he adds some biographic details about the difficulties of life in prison and finding work upon release. In the same season, we find Gerald in a similar situation, unemployed as a result of failed drug tests at Big Dog Drilling. Apparently Gerald underwent treatment in a substance abuse program before passing a second drug test, an ordeal experienced in the driller's estimation by $90 \%$ of roughnecks. We are told that while unemployment is pervasive in West Texas, few men seek out a life of roughnecking and even fewer are able to persevere, making experienced hands like Tank and Gerald particularly valuable. While the veteran roughnecks are eventually rehired, they are often shown intoxicated at local bars and failing to arrive at work, footage that accentuates character flaws of some roughnecks and the deficiencies of the existing labor pool in West Texas. The inclusion of the drug test as industry protocol and program content would suggest that workplace injuries are the result of slipshod and intoxicated workers rather than the torrid pace of drilling set by owners and enforced by tool pushers. Here problems of production apparently rest with unreliable workers rather than the avarice of capital.

If Black Gold frames drug use in the neoliberal terms of self-management and what Freddy calls "extracurric'lar activities," Coal places drug use firmly within the strained relations of production. 
After partaking in a random drug test at Cobalt, workers express their displeasure onscreen. While some miners taunt their employers to the camera, others provide more sobering reflections on the connections between narcotics and the hardships of coalmining.

Look at the environment. You're crawling in a water hole. You're crawling between two rocks. Do it ten or eleven hours a day for thirty-three years. Can you imagine getting up in the morning and not being stiff, and not hurting? Could you imagine going through a day without pain? A man can't work in these conditions and not feel pain, and not take a pain pill from time to time.

For this particular miner, the pain and breakdown of the body is the result of coalmining, which provides an income as long as he refrains from using the barbiturates that enable and sustain daily travail in the first place. Most workers in these television programs see their toil and by extension their bodies as the key but ephemeral source of value, which is prone to degradation. Whereas the drug test "enables corporate 'experts' in attitudes and bodily fluids to assess the purity of employees" and situate "the human body ... as a site of rationalization ... efficiency and productivity," Coal provides an important riposte ([19], p. 92). It suggests that the consumption of drugs and medication is a way of "putting the body right" and "returning to work" rather than hedonistic escape ([8], p. 114). To this end, Coal offers lucid reflections on the working body and expendability.

\section{Masculinity by Proxy and the Popular Pedagogy of Paid Labor Shows}

The images of burly white men on paid labor shows are perhaps more nostalgic than nuanced, marking yet another symbolic return to working-class bodies as a proxy for masculinity. In fact popular depictions of working-class 'manliness' have often been used to compensate for the perceived emasculation of middle-class men in the sedentary environment of the office [35]. As Edward Slavishak notes, in steel towns of the early 1900s representations of "industrial workers offered some solace to those who envisioned the physical weakening that accompanied white-collar employment" [36]. While the stalwart masculinity personified by muscle workers was predicated on a "repudiation of the feminine," it was also rooted in labor militancy, physical defiance and irreverence for employers ([35], p. 60). To be manly, in other words, was to reject what Michael Kimmel describes as the "scrawny, feeble-bodied" office boy as well as the 'ball-breaking' factory owner ([35], p. 61). Against an image of the rabblerousing industrial worker, of course, was the white-collar man, who C. Wright Mills once described as "the small creature who is acted upon but who does not act, who works along unnoticed in somebody's office or store, never talking aloud, never talking back, never taking a stand" [37]. Essentially, striking miners and puddlers embodied the antithesis of the clerical worker's deskbound docility and were often depicted in a rigid vernacular of hegemonic masculinity.

Paid labor shows provide a similar proxy of masculinity for middle-class men, particularly those affected by unemployment and the market collapse of 2008. Indeed, Ax Men, Black Gold and Coal seem to target middle-class male viewers in both subtle and overt ways. Dialogue in each series is laden with profanity and misogynistic remarks as workers refer to weak hands as "thin-skinned women," telling them to "man up." Some dialogue is also accompanied by subtitles that situate loggers, roughnecks and miners as socioeconomic strangers but also help to educate middle-class viewers. While the workers themselves seem to abhor "city slickers" and "pretty boys" (one of whom in Black Gold drives a Mercedes-Benz sedan), each series presents pop-up messages as CliffsNotes for 
the uninitiated urbanite. In Black Gold, for example, viewers are encouraged to "learn roughneck slang," hear from "real roughnecks on the message board" and read details of "Gerald's worst accident ever." Some messages even offer the viewer "roughneck secrets" to saving money on gasoline. In $A x$ Men, pop-up messages direct us to the network website that describes a "day in the life" of a logger and his alternative career path. Each series assumes the audience is unfamiliar with a proletarian patois and provides a glossary of working-class terms. In short, paid labor shows translate working-class life and sometimes labor conflicts in ways that enable and encourage middle-class voyeurism; at trutv.com viewers can read what roughnecks "really think of their supervisors."

What distinguishes past from present narratives of muscle work as masculine redemption, however, is the extent to which the latter is embedded within a bloated consumer culture, one that emphasizes the appearance of the body as "ersatz use-value" [38]. As Mike Featherstone explains, "The perception of the body in consumer culture is dominated by the existence of a vast array of visual images," which encourage shoppers to imagine their bodies as projects to be disciplined and decorated in various ways ([38], p. 170). Whereas the body becomes a floating signifier adrift from any fixed or material meanings, the "central feature of commodified society" is "the abstraction of social products and practices from the laboring bodies that generate them" ([34], p. 1). In paid labor shows this works in complicated ways. To illustrate, viewers of Ax Men, Black Gold and Coal can now express their masculinity and affinity for each series not by logging, roughnecking or mining but rather through brand allegiance, adorning their (sedentary) bodies with fan gear like t-shirts, hooded sweatshirts and hats emblazoned with the series (and company) logos. In a sense, the celebration of labor and working bodies shifts from a language of use-value to one of sign-value whereby the "painful, heroic Age of Production" is processed and packaged for the "euphoric Age of Consumption" [39]. Under such conditions, viewers are encouraged to support loggers, roughnecks and miners by purchasing swag rather than empathizing or campaigning for improved work conditions, profit sharing or the right to organize. Online retailers and network websites position the working body as a sign-commodity of manliness predicated on dirt, degradation and danger, which are disconnected from the relations of production. Here the laboring body becomes fetishized as a site of not only romanticized masculinity but also risk entertainment for consumers.

Some of the cast however, is quite conscious of manliness as an empty signifier. When a rookie logger fails to arrive at work in Ax Men, the crew of Siderius logging concludes that his "big muscles are just for show" and have little practicality in the workplace. (The rookie wears sleeveless shirts that display his bulging and tattooed biceps.) In Black Gold, tool pushers rib a young roughneck for having "lots of muscles but no idea about technique." In such episodes, the body is understood and appreciated for its pragmatic rather than aesthetic value. Together, paid labor shows and their merchandising may imply that if the body has become a central focus of consumerism, it is still very much a working body. However, the same working bodies that provide surplus value for logging, drilling and mining companies also provide value for the reality programs and their merchandise. Of course one of the most profitable attributes of reality television is the extent to which it reduces the costs of labor, relying mainly on non-unionized non-actors for its storylines. In this sense, work in $A x$ Men, Black Gold and Coal can be understood as both material and immaterial; all reality television participants are workers in a "social factory," regardless of the programming content [26]. 
Paid labor shows and their nostalgic images of rugged white masculinity, then, present a complicated popular pedagogy of late capitalism and the body. An obvious limitation is the genre's skewed depiction of working bodies, which elides the demographic diversity of the working class. In addition, the saturation of service-sector employment in North America and what Swados called the "proletarianization" of the middle class renders paid labor shows slightly anachronistic in their portrayal of meaningful work ([21], p. 244). The classic narratives of working-class masculinity polarize mental and physical labor and occlude possible lines of solidarity with disgruntled whitecollar, intellectual and affective workers. As Braverman pointed out, "the dissatisfaction of the assembly-line and blue-collar worker is mirrored in white-collar and even managerial positions ... where work is segmented and authoritarian" ([13], p. 34). At a time when "violent assaults on all forms of labor organization and labor rights" abound, conflict in Ax Men, Black Gold and Coal is all but disconnected from widespread labor struggles that include, for instance, teachers in Wisconsin, screenwriters in Hollywood, chambermaids in California, Wal-Mart employees in Quebec as well as airline attendants, pilots, baggage handlers and postal workers across Canada [40]. In fact, service industries are openly derided by roughnecks and loggers as women's work. Within the representations of labor there is also a disavowal of the labor of representation; workers are pitched as 'real men' in real work environments rather than actors or entertainers in a studio. This appeal to 'authenticity' is presumably used to distinguish work from play, mistaking the culture industry for an apolitical entity. As a popular pedagogy, then, Ax Men, Black Gold and Coal may curtail the conditions of possibility for what Michael Hardt and Antonio Negri call "the multitude," a moniker for "all those who work under the rule of capital and thus potentially ... a class of those who refuse the rule of capital" across both material and immaterial (or affective) industries [41].

But these narratives of working bodies also disrupt a middle-class discourse of the Great Recession. In and beyond slick Hollywood films like Wall Street: Money Never Sleeps, Too Big to Fail and Margin Call, for instance, late capitalism is "driven by credit and speculation" and assumes a rather "fictitious" quality that "inflates capital's autonomy from labor and productive activity" ([34], p. 46). In other words, "money-capital is treated as self-generating, without an origin in labor" ([34], p. 63). In Ax Men, Black Gold and Coal, however, we find not only the return of labor but, moreover, the reembodiment of value as loggers, roughnecks and miners risk both life and limb to reach company quotas. Each program suggests that even in a vertiginous climate of subprime lending, collateralized debt obligations, mortgage-backed securities, a liquidity shortfall and widespread middle-class unemployment, somebody is still working in fields, factories and mines, toiling, digging and sweating to provide for the rest of society [34]. As Nick Dyer-Witheford suggests, "The new circuits of capital ... look a lot less 'immaterial' and 'intellectual' to the ... workers who do so much of the grueling physical toil" [42]. In an era of "virtual economies of pure speculation," then, the working bodies of $A x$ Men, Black Gold and Coal "obstinately refuse to dematerialize themselves" ([42], p. 76). They seem to suggest that any attempt to "banish the real human body - the sensate, biocultural, laboring bodyfrom the sphere of ... social [and economic] life" is deeply misguided ([34], p. 1). The problem, of course, is that 'real human bodies' of paid labor shows belong almost exclusively to white men, who are imagined to be the historical fulcrum of a cutthroat capitalism; they are presented as the most heroic of workers but also the most victimized by the vicissitudes of the market, a grossly misleading assertion [43]. 


\section{Conclusions}

In 2002, social historian Michael Denning asked polemically how labor gets "turned into beauty, particularly since we usually don't want to look at it" [44]. His query speaks to a widespread denigration of work and the abstraction and abjection of labor in consumer culture and popular media. With the recent deluge of paid labor shows, however, it seems that images of work are quite desirable, but only in circumspect ways. While some critics claim that the "tepid populism" of paid labor shows trivializes "tension between the toilers and the profiteers," the muckraking narratives of used and abused working bodies provide an oblique critique of late capitalism [45]. Remiss of unions or collective organizing, Ax Men, Black Gold and Coal may not "supply the millennial answer to the popular labor novels of the late-nineteenth and early-twentieth centuries," but they do offer a glimpse of how surplus value remains embodied even in an era of post-industrialism and service-sector (un)employment [45]. Requisite of consumer culture, however, the working bodies of paid labor shows are converted from use-value to sign-value in the mediated marketplace of reality television, providing viewers with virulent and consumable emblems of brawny manliness in times of need. Evidently, only certain types of work are desirable and deemed profitable on cable television. Only certain types of working bodies matter.

With narratives of masculinity by proxy, paid labor shows provide an appendix to Hollywood films about the Great Recession and their cursory attention to the working classes. In both cases, however, the crisis of labor is also presented as a crisis of white masculinity, making each text an important but shortsighted intervention into the ill effects of late capitalism and neoliberalism. Images of working bodies in paid labor shows discourage the audience from drawing important connections between a multitude of workers that converge around a similar set of economic conditions and relations of production; that the "multiplicity" of labor finds "singularity" in a "common substrate" of neoliberalism is overlooked in the labor commentaries of Ax Men, Black Gold and Coal ([41], p. 125). While these paid labor shows expand our understanding of the recession beyond the middle class, they also narrow the definitions of the working class and conflict during the Great Recession. On the one hand, "static definitions of class that continue to rely on a particular type of work as the primary point of reference" are bound to lose "pertinence" in the present [46]. On the other hand, the emphasis on struggling white men in paid labor shows also complements the reactionary political platform of the Tea Party and closely resembles the plebeian protagonist of the McCain-Palin campaign of 2008: Joe the Plumber. Here "The idea of a body hard at work has the power to attract votes, the power to sell products and the power to win symbolic struggles" ([12], p. 148). The heroic working body of leftist rhetoric, in other words, is polysemic and can bend in multiple political directions.

However, if paid labor shows are read alongside demographic shifts and the proletarianization of the middle class as well as recent Hollywood commentaries on class, they might participate in an aggregate but rather robust critique of late capitalism, one that situates the body as a source of sustenance and a conduit of class struggle. In other words, paid labor shows can and perhaps should be understood as part of a tapestry of class-conscious visual media that now includes a broadly-conceived working-class leitmotif in Hollywood. Whereas films made about the economic collapse describe the disappearance of white-collar jobs and the erosion of the middle class, films released during the Great Recession constitute a more expansive set of labor texts across a spectrum of sports, action-adventure, 
science - and historical-fiction as well as comedy and combat films. From The Fighter (2010), Unstoppable (2010) and Repo Men (2010) to The Expendables (2010), The Other Guys (2010) and The Help (2011) labor, it seems, is everywhere! In such films we may find what Stanley Aronowitz calls "refractive narratives of working-class history" where themes of class struggle and labor politics emerge more or less obliquely according to the narrative and aesthetic conventions of a particular genre [47]. Alongside these films, paid labor shows supplement a wider working-class commentary in and across media culture to provide a "stage for the dramatizing of contemporary class relations," one that emphasizes the body as a source of capital, control and conflict [29].

\section{References and Notes}

1. Peck, D. Can the middle class be saved? The Atlantic, September 2011. Available online: http://www.theatlantic.com/magazine/archive/2011/09/can-the-middle-class-be-saved/8600/ (accessed on 5 November 2011).

2. de Guerre, M. The End of Men (documentary film); Red Apple Production: Toronto, Canada, 2011.

3. Marin, R. Dead suit walking. The Daily Beast, 17 April 2011. Available online: http://www.thedailybeast.com/newsweek/2011/04/17/dead-suit-walking.html (accessed on 27 April 2012).

4. Rosin, H. The end of men. The Atlantic, July/August 2010. Available online: http://www.theatlantic.com/magazine/archive/2010/07/the-end-of-men/8135/ (accessed on 10 December 2011).

5. Mills, C.W. Letter to the New Left. NLR 1960, 5, 9.

6. Kellner, D. Media Culture; Routledge: London, UK, 1995.

7. Douglas, M. Natural Symbols: Explorations in Cosmology; Routledge: London, UK, 1970.

8. Shilling, C. The Body and Social Theory, 2nd ed.; Sage: London, UK, 2003; p. 65.

9. Bourdieu, P. Distinction: A Social Critique of the Judgment of Tastes; Nice, R. Trans.; Harvard University Press: Cambridge, MA, USA, 1984.

10. Goffman, E. The Presentation of Self in Everyday Life; Double Day/Anchor Books: New York, NY, USA, 1959.

11. Orwell, G. The Road to Wigan Pier; Penguin: New York, NY, USA, 1937; p. 114.

12. Slavishak, E. "Made by the work": A century of laboring bodies in the United States. In The Body Reader; Moore, L., Kosut, M. Eds.; New York University Press: New York, NY, USA, 2010; pp. 147-163.

13. Braverman, H. Labor and Monopoly Capital: The Degradation of Work in the Twentieth Century; Monthly Review Press: New York, NY, USA, 1974.

14. Rose, N. Governing the Soul: The Shaping of the Private Self, 2nd ed.; Free Association Books: London, UK, 1999.

15. Balsamo, A. Forms of technological embodiment: Reading the body in contemporary culture. In Cyberspace, Cyberbodies, Cyberpunk: Cultures of Technological Embodiment; Featherstone, M., Burrows, R., Eds.; Sage: Thousand Oaks, CA, USA, 1995; pp. 215-238. 
16. Gonzalez, G. Guest Workers or Colonized Labour? Mexican Labour Migration to the United States; Paradigm: Boulder, CO, USA, 2006; p. 2.

17. Ross, B. Bumping and grinding on the line: Making nudity pay. Labour/Le Travail. 2000, 46, 221-250.

18. Lessor, R. Consciousness of time and time for the development of consciousness: Health awareness among women flight attendants. Sociol. Health Illness 1984, 6, 191-213.

19. Hancock, P., Tyler, M. Working bodies. In The Body, Culture and Society; Hancock, P., Hughes, B., Jagger, E., Patterson, K., Russell, R., Tulle-Vinston, E., Tyler, M., Eds.; Open University Press: Buckingham, UK, 2000; pp. 84-100.

20. Romano, P.; Stone, R. The American Worker; Bewick/Ed: Detroit, MI, USA, 1947.

21. Swados, H. On the Line; University of Illinois Press: Urbana-Champaign, IL, USA, 1957.

22. Hamper, B. Rivethead: Tales from the Assembly Line; Warner Books: New York, NY, USA, 1986.

23. Ehrenreich, B. Nickel and Dimed: On (Not) Getting By in America; Henry Holt \& Company: New York, NY, USA, 2002.

24. Hall, S.; Grosserg, L. On postmodernism and articulation: An interview with Stuart Hall. In Stuart Hall: Critical Dialogues in Cultural Studies; Morley, D., Chen, K-H., Eds.; Routledge: London, UK, 1996; pp. 131-150.

25. Andrejevic, M. Reality TV: The Work of Being Watched; Rowman and Littlefield: New York, NY, USA, 2004.

26. Deery, J. Reality TV as advertainment. Popular Comm. 2004, 2, 1-20.

27. Hearn, A. "John, a 20-year-old Boston native with a great sense of humour": On the spectacularization of the "self" and the incorporation of identity in the age of reality television. Int. J. Media Cult. Polit. 2006, 2, 131-147.

28. Raphael, C. The political economic origins of Reali-TV. In Reality TV: Remaking Television Culture; Murray, S., Ouellette, L., Eds.; New York University Press: New York, NY, USA, 2004; pp. 119-136.

29. Wood, H.; Skeggs, B. Spectacular morality: Reality television, individualization and the remaking of the working class. In The Media and Social Theory; Hesmondhalgh, D., Toynbee, J., Eds.; Routledge: London, UK, 2008; pp. 177-193.

30. Poniewozik, J. Reality TV's working class heroes. Time, 22 May 2008. Available online: http://www.time.com/time/magazine/article/0,9171,1808612,00.html (accessed on 14 April 2012).

31. Slavishak, E. Artificial limbs and industrial workers' bodies in turn-of-the-century Pittsburgh. $J$. Soc. Hist. 2003, 37, 365-388.

32. McClintock, A. Screwing the system: Sexwork, race and the law. Boundary 2 1992, 19, 71-95.

33. Essig, L. Dirt and death and the Occupy Movement. The Chronicle of Higher Education, 15 November 2011. Available online: http://chronicle.com/blogs/brainstorm/dirt-and-death-and-theend-of-the-occupy-movement/41326 (accessed on 19 March 2012).

34. McNally, D. Bodies of Meaning: Studies on Language, Labor and Liberation; State University of New York Press: Albany, NY, USA, 2001; p. 6.

35. Kimmel, M. Manhood in America: A Cultural History; Simon and Schuster: New York, NY, USA, 1996. 
36. Slavishak, E. Bodies of Work: Civic Display and Labor in Industrial Pittsburgh; Duke University Press: Durham, UK, 2008; p. 100.

37. Mills, C.W. White Collar: The American Middle Classes; Oxford University Press: Oxford, UK, 1951; p. xii.

38. Featherstone, M. The body in consumer culture. In The Body; Featherstone, M., Hepworth, M., Turner, B., Eds.; Sage: London, UK, 1991; pp. 170-196.

39. Baudrillard, J. The Consumer Society: Myths and Structures; Sage: London, UK, 1989; p. 82.

40. Harvey, D. A Brief History of Neoliberalism; Oxford University Press: Oxford, UK, 2005; p. 76.

41. Hardt, M.; Negri, A. Multitude: War and Democracy in the Age of Empire; Penguin Books: New York, NY, USA, 2004; p. 106.

42. Dyer-Witheford, N. Empire, immaterial labor, the new combinations, and the global worker. Rethinking Marx. 2001, 13, 70-80.

43. See Giroux, H. Zombie Politics and Culture in the Age of Casino Capitalism; Peter Lang: Boulder, CO, USA, 2010.

44. Denning, M. Work and culture in American Studies. In The Future of American Studies; Pease, D., Wiegman, R., Eds.; Duke University Press: Durham, UK, 2002; pp. 419-440.

45. Bellafante, G. Workers of an extreme world, one beyond classes. New York Times, 18 June 2008. Available online: http://www.nytimes.com/2008/06/18/arts/television/18beer.html?_r=2 (accessed on 15 May 2012).

46. Purcell, K.W. Reimagining the working class from Riff-Raff to Nil by Mouth. In Looking at Class: Film, Television and the Working Class in Britain; Rowbotham, S., Beynon, H., Eds.; Rivers Oram Press: London, UK, 2001; pp. 113-131.

47. Aronowitz, S. Working-class culture in the electronic age. In Cultural Politics in Contemporary America; Angus, I., Jhally, S., Eds.; Routledge: London, UK, 1989; pp. 135-150.

(C) 2012 by the author; licensee MDPI, Basel, Switzerland. This article is an open access article distributed under the terms and conditions of the Creative Commons Attribution license (http://creativecommons.org/licenses/by/3.0/). 